\title{
Effect of Dedhuwa (Esomus danricus), Mara (Amblypharyngodon mola) and Pothi (Puntius sophore) on Carp Production in Chitwan, Nepal
}

\author{
M.C. Gupta* and S. Rai \\ Institute of Agriculture and Animal Science, Rampur, Chitwan, Nepal \\ *E-mail: maheshgupta111@gmail.com
}

Received: 19.09.2009, Accepted: 26.11.2010

\begin{abstract}
In order to assess the effect of adding Dedhuwa (Esomus danricus), Mara (Amblyparyngodon mola) and Pothi (Puntius sophore) on Carp production, an experiment was carried out in farmers' pond in Chitwan. The experiment included four treatments in triplicates: $\mathrm{T}_{1}$, (Carp: Silver carp, Hypophthalmychthys molitrix, Bighead carp, Aristichthys nobilis, Rohu, Labeo rohita and Mrigal, Cirrhinus mrigala), $\mathrm{T}_{2}$ (Carp+Dedhuwa), $\mathrm{T}_{3}$ (Carp+Mara), and $\mathrm{T}_{4}$ (Carp+Pothi). Fish were fed on dough of rice bran and mustard oil cake $(1: 1)$ at the rate of $3 \%$ of body weight. Results showed that Dedhuwa, Mara and Pothi did not differ significantly $(\mathrm{P}>0.05)$ in terms of production. Production of Silver carp and Bighead carp was found significantly higher $(\mathrm{P}<0.05)$ in $\mathrm{T}_{3}$ and $\mathrm{T}_{4}$ than control indicating no niche overlapping among these fish. Based on total production and profit $\mathrm{T}_{4}$ appeared to be best.
\end{abstract}

Key words: Dedhuwa, Pothi, Mara, Carp polyculture

\section{Introduction}

Small indigenous fish species (SIS) are highly valuable source of macro and micronutrients that play an important role to provide essential nutrients for the people. Vitamins and minerals are found to be much more in small fish than in large fish such as Carp. Dedhuwa (Esomus danricus Hamilton-Buchanan), Mara (Amblypharyngodon mola Hamilton-Buchanan) and Pothi (Puntius sophore Hamilton-Buchanan) are rich in iron, vitamin-A and calcium, respectively. Dedhuwa contains $12 \mathrm{mg}$ Iron which is three times higher than in Silver carp (Hypophthamichthys molitrix Hamilton-Buchanan). Similarly, vitamin-A content in Mara is 2,680 RAE which is 90 times higher than in Silver carp whereas Pothi contains $784 \mathrm{mg}$ calcium in $100 \mathrm{~g}$ raw, cleaned parts while Silver carp contains 36 mg calcium (Roos et al., 2006). The bones of SIS are very rich in calcium. Likewise, the eyes, head, organs and viscera of some SIS, such as Mola are rich in vitamins and minerals, especially vitamin A, iron and zinc. Since SIS are eaten whole, without loss of nutrients from cleaning or as plate waste, contribution of SIS on micronutrients intake is higher than large Carp. These nutrients are found to be highly boiavailable in SIS. Studies in poor, rural households in Bangladesh and Cambodia showed that a small production of the vitamin A-rich fish, Mola in household ponds can meet the annual vitamin A recommendation of 2 million Bangladeshi children and a traditional, daily meal with the iron-rich small fish, trey changwa plieng (Esomus longimanus Hamilton-Buchanan) 
M.C. Gupta and S. Rai / Our Nature (2011) 9: 112-118

can meet $45 \%$ of the daily median iron requirement of Cambodian women (Roos et al., 2007). Moreover, SIS is self recruiting fish and are therefore, can be harvested weekly and biweekly, favouring household consumption.

Preliminary research on polyculture of Carp, SIS such as Dedhuwa and Pothi, and Prawn in Chitwan showed that there is a potential of such polyculture system in terai (Yadav, 2011). Incorporating Dedhuwa and Pothi in Carp ponds indeed increased nutrients intake and income generation among farmers. Therefore, there is a need of studies with other high nutrient containing SIS such as Mara in polyculture. The present experiment is therefore to assess the effect of incorporating Dedhuwa, Mara and Pothi on Carp production in Carp polyculture ponds in Chitwan, Nepal.

\section{Materials and methods}

The experiment was conducted at Majhui, Khaireni Village Development Committee-3 of Chitwan district for 270 days. The experiment was conducted in 15 newly constructed ponds of approximately $100 \mathrm{~m}^{2}$ $\left(75 \mathrm{~m}^{2}-133 \mathrm{~m}^{2}\right)$. The experiment was conducted in completely randomized design (CRD). There were four treatments and each with three replications. Treatments included $\mathrm{T}_{1}$, Carp only (Silver carp, Bighead carp, Rohu and Mrigal), $T_{2}$ (Carp+Dedhuwa), $T_{3}$ (Carp+Mara), and $\mathrm{T}_{4}$ (Carp+Pothi). The stocking density of Carp and SIS were 100 (Silver carp 40, Bighead carp 15, Rohu 25, and Mrigal 20) and 300 per $100 \mathrm{~m}^{2}$ respectively. The mean stocking size of Silver carp, Bighead carp, Rohu, Mrigal, Dedhuwa, Mara and Pothi were $2.72 \pm 0.25$ g, $7.15 \pm 2.04 \mathrm{~g}, 34.84 \pm 2.11 \mathrm{~g}, 6.10 \pm 0.87 \mathrm{~g}$, $0.99 \pm 0.01 \mathrm{~g}, 1.39 \pm 0.01 \mathrm{~g}$, and $1.94 \pm 0.04 \mathrm{~g}$, respectively. Water fertility was maintained by applying cow dung, urea and DiAmmonium Phosphate (DAP) regularly at the rate of $0.4 \mathrm{~g} \mathrm{~N} / \mathrm{m}^{2} /$ day and $0.1 \mathrm{~g}$ $\mathrm{P} / \mathrm{m}^{2} /$ day (Shrestha and Pandit, 2007). Fish were fed on dough of rice bran and mustard oil cake $(1: 1)$ at the rate of $3 \%$ of body weight.

Composite water samples representing the entire pond water column were taken for analysis. Physical water quality parameters $(\mathrm{DO}, \mathrm{pH}$, temperature, transparency and water depth) were measured weekly at 7.00-9.00 am in situ where as chemical water quality parameters (total alkalinity, soluble reactive phosphorous, total ammonium nitrogen and chlorophyll- $a$ ) were analyzed monthly.

At least $20 \%$ fishes were netted monthly for sampling. Dedhuwa, Mara and Pothi were regularly harvested after three months of its stocking because these are self recruiting species. Final harvesting of all Carp and SIS was done after complete draining of each pond. During harvest, all fishes were counted and weighed separately to assess survival rate and production.

Experimental data were analyzed by using one-way ANOVA using SPSS, 16.0. Mean differences were compared using the DMRT after ANOVA. Differences were considered significant at an alpha level of $0.05(\mathrm{p}<0.05)$. All means were given with \pm 1 standard error (S.E.).

\section{Results}

Water quality parameters did not vary among treatments $(\mathrm{P}>0.05$, Tab. 1$)$.

Final total weight and total weight gain of Silver carp was significantly higher $\left(\mathrm{P}<0.05\right.$, Tabs. 2, 3) in $\mathrm{T}_{3}$ and $\mathrm{T}_{4}$ than $\mathrm{T}_{1}$ but was not significantly different than $T_{2}$ $(\mathrm{P}>0.05)$. Initial mean weight of Bighead carp was significantly higher $(\mathrm{P}<0.05)$ in $\mathrm{T}_{1}$ 


\section{M.C. Gupta and S. Rai / Our Nature (2011) 9: 112-118}

than $T_{2}, T_{3}$ and $T_{4}$. Final mean weight of Bighead carp was significantly higher $(\mathrm{P}<0.05)$ in $\mathrm{T}_{4}$ than $\mathrm{T}_{2}$ while it was not significantly different $(\mathrm{P}>0.05)$ from that of $\mathrm{T}_{1}$ and $\mathrm{T}_{3}$. Total weight gain of Bighead carp was significantly higher $(\mathrm{P}<0.05)$ in $\mathrm{T}_{3}$ and $\mathrm{T}_{4}$ than $\mathrm{T}_{1}$. Final mean weight, survival, daily weight gain and total weight gain of Rohu and Mrigal did not differ significantly $(\mathrm{P}>0.05)$ among treatments. Total weight gain of Dedhuwa, Mara and Pothi were $2.56,0.98,4.04 \mathrm{~kg} / 100 \mathrm{~m}^{2}$ in $\mathrm{T}_{2}, \mathrm{~T}_{3}$ and $\mathrm{T}_{4}$, respectively.

Net yield of Carp and combined total net fish yield was significantly higher $\left(\mathrm{P}<0.05\right.$, Tab. 4) in $\mathrm{T}_{4}$ than $\mathrm{T}_{1}$ while it was not significantly different $(\mathrm{P}>0.05)$ from that of $T_{2}$ and $T_{3}$. Contributions of Carp to total production in $T_{2}, T_{3}$ and $T_{4}$ were 89.7, 96.0 and $87.0 \%$ while that of SIS was $10.3,4$ and $13 \%$, respectively. Apparent food conversion ratio did not vary significantly $(\mathrm{P}<0.05)$ among treatments.

Variable costs involved in fish production were not significantly different $(\mathrm{P}>0.05$, Tab. 5) among treatments. Total gross return was higher in $\mathrm{T}_{4}$ (NRs. $6,915 \pm 501$ ) and lower in $\mathrm{T}_{1}$ (NRs. $4,889 \pm 336$ ) but was not significantly different $(\mathrm{P}>0.05)$ from that of $\mathrm{T}_{2}$ and $\mathrm{T}_{3}$. Gross margin was higher in $\mathrm{T}_{4}$ (NRs. $574,130 \pm 106,530 / \mathrm{ha} / \mathrm{yr}$ ) than rest treatments.

\section{Discussion}

All the water quality parameters were within the suitable range for Carp. Water remained muddy brown instead of green during rainy season due to dike run off as ponds were newly constructed and dikes were uncovered. In addition, canal water used to top the pond was also muddy brown. The non-algal turbidity is caused by suspended clay particles (Boyd, 1990) due to erosion of newly constructed pond dikes, run off from the dike and use of muddy canal water during rainy season.

The production of Dedhuwa, Mara, and Pothi did not differ significantly $(p>0.05)$ among treatments. However, their effect on growth and production of Carp was apparent. Total weight gain of Silver carp was significantly higher $(\mathrm{P}<0.05)$ in $\mathrm{T}_{3}$ and $\mathrm{T}_{4}$ than other treatments. This might be due to no niche overlapping with Mara and Pothi. Mara and Pothi are omnivore while Silver carp is a phytoplankton feeder (Wahab and Kadir, 2009). Silver carp is a surface feeder while Pothi is a bottom feeder. So, different feeding habits and habitat reduced interspecific competition between Silver carp and both SIS. Despite larger stocking size $(\mathrm{P}<0.05)$ in $\mathrm{T}_{1}$, final total weight gain of Bighead carp was found significantly higher $(\mathrm{P}<0.05)$ in $\mathrm{T}_{3}$ and $\mathrm{T}_{4}$ than $T_{2}$ indicating that Mara and Pothi had positive effect on its growth and production. Perhaps no food competition occurred between Bighead carp and Mara and Pothi because both Mara and Pothi are omnivore (Wahab and Kadir, 2009). Growth rates of Silver carp, Bighead carp, Rohu and Mrigal was not significantly different $(p>0.05)$ among treatments indicating SIS independent growth. The growth rate was found highest in Rohu $(1.21 \pm 0.12 \mathrm{~g} / \mathrm{f} / \mathrm{d})$ followed by Mrigal (1.17 $\pm 0.16 \mathrm{~g} / \mathrm{f} / \mathrm{d})$, Silver carp $(1.09 \pm 0.08 \mathrm{~g} / \mathrm{f} / \mathrm{d})$ and Bighead carp $(0.87 \pm 0.27 \mathrm{~g} / \mathrm{f} / \mathrm{d})$

Net Carp yield and total net fish yield was significantly higher $(\mathrm{P}<0.05)$ in $\mathrm{T}_{4}$ than $\mathrm{T}_{1}$, which can be attributed to positive effect of Pothi on Carp leading to better growth and production of Carp in the treatment. The net Carp yield in the present experiment was higher than as reported by Miah et al. 
M.C. Gupta and S. Rai / Our Nature (2011) 9: 112-118

Table 1. Summary of water quality parameters in different treatments during experimental period (Mean \pm S.E.)

\begin{tabular}{lcccc}
\hline \multirow{2}{*}{ Parameters } & \multicolumn{4}{c}{ Treatment } \\
\cline { 2 - 5 } & $\mathbf{T}_{\mathbf{1}}$ & $\mathbf{T}_{\mathbf{2}}$ & $\mathbf{T}_{\mathbf{3}}$ & $\mathbf{T}_{\mathbf{4}}$ \\
\hline Temperature $\left({ }^{\circ} \mathrm{C}\right)$ & $28.9 \pm 0.2$ & $28.8 \pm 0.5$ & $28.9 \pm 0.4$ & $29.2 \pm 0.1$ \\
& $(23.8-31.1)$ & $(22.8-31.7)$ & $(23.5-32.4)$ & $(24.0-32.2)$ \\
\hline Dissolved Oxygen $(\mathrm{mg} / \mathrm{L})$ & $6.7 \pm 0.4$ & $6.1 \pm 0.7$ & $6.1 \pm 0.7$ & $7.0 \pm 0.1$ \\
& $(3.5-9.3)$ & $(3.9-8.0)$ & $(3.0-8.4)$ & $(4.4-9.3)$ \\
\hline $\mathrm{pH}$ & $8.2 \pm 0.0$ & $8.2 \pm 0.2$ & $8.2 \pm 0.2$ & $8.2 \pm 0.2$ \\
& $(7.9-8.9)$ & $(7.9-8.8)$ & $(7.8-8.9)$ & $(7.7-8.7)$ \\
\hline Secchi disk depth $(\mathrm{cm})$ & $27.1 \pm 1.7$ & $24.1 \pm 1.4$ & $28.6 \pm 0.7$ & $26.6 \pm 0.4$ \\
& $(19.2-33.0)$ & $(20.7-26.7$ & $(22.3-29)$ & $(19.3-26.3)$ \\
\hline Total alkalinity $\left(\mathrm{mg} / \mathrm{L} \mathrm{Ca} \mathrm{CO}_{3}\right)$ & $104.8 \pm 5.3$ & $106.4 \pm 2.7$ & $107.7 \pm 5.6$ & $112.7 \pm 4.8$ \\
& $(89.9-156.0)$ & $(86.4-125.6)$ & $(90.3-121.4)$ & $(88.9-121.9)$ \\
\hline Chlorophyll- $a\left(\mathrm{mg} / \mathrm{m}^{3}\right)$ & $17.8 \pm .3$ & $15.12 \pm 3.21$ & $18.48 \pm 1.82$ & $18.8 \pm 1.87$ \\
& $(7.3-26.97)$ & $(7.1-28.9)$ & $(7.6-31.9)$ & $(6.7-29.3)$ \\
\hline Total ammonium nitrogen & $0.040 \pm 0.002$ & $0.041 \pm 0.002$ & $0.048 \pm 0.003$ & $0.042 \pm 0.025$ \\
(mg/L) & $(0.006-0.072)$ & $(0.019-0.075)$ & $(0.024-0.079)$ & $(0.029-0.067)$ \\
\hline Soluble reactive phosphorus & $0.024 \pm 0.005$ & $0.025 \pm 0.007$ & $0.027 \pm 0.006$ & $0.028 \pm 0.004$ \\
(mg/L) & $(0.013-0.034)$ & $(0.001-0.053)$ & $(0.015-0.084)$ & $(0.009-0.093)$ \\
\hline Mean valus with differ & &
\end{tabular}

Mean values with different superscript letters in the same row are significantly different $(\mathrm{P}<0.05)$.

Table 2. Growth performance of Carp in different treatments (Mean \pm S.E.).

\begin{tabular}{|c|c|c|c|c|}
\hline \multirow{2}{*}{ Parameters } & \multicolumn{4}{|c|}{ Treatments } \\
\hline & $\mathbf{T}_{1}$ & $\overline{T_{2}}$ & $\mathbf{T}_{3}$ & $\mathbf{T}_{4}$ \\
\hline \multicolumn{5}{|l|}{$\overline{\text { Silver carp }}$} \\
\hline Initial mean weight (g/fish) & $3.46 \pm 1.33$ & $2.70 \pm 0.08$ & $2.52 \pm 0.05$ & $2.60 \pm 0.01$ \\
\hline Initial total weight $\left(\mathrm{kg} / 100 \mathrm{~m}^{2}\right)$ & $0.14 \pm 0.05$ & $0.10 \pm 0.00$ & $0.10 \pm 0.00$ & $0.10 \pm 0.00$ \\
\hline Final mean weight (g/fish) & $296.35 \pm 6.05$ & $266.89 \pm 14.06$ & $311.14 \pm 4.46$ & $309.09 \pm 16.60$ \\
\hline Final total weight $\left(\mathrm{kg} / 100 \mathrm{~m}^{2}\right)$ & $7.78 \pm 0.94^{\mathrm{b}}$ & $9.15 \pm 0.03^{\mathrm{ab}}$ & $11.15 \pm 0.28^{\mathrm{a}}$ & $11.28 \pm 0.82^{\mathrm{a}}$ \\
\hline Survival (\%) & $65.6 \pm 8.6$ & $91.2 \pm 1.9$ & $85.7 \pm 3.9$ & $89.6 \pm 2.5$ \\
\hline Daily weight gain (g/f/d) & $1.08 \pm 0.02$ & $0.97 \pm 0.04$ & $1.14 \pm 0.01$ & $1.13 \pm 0.06$ \\
\hline Total weight gain $\left(\mathrm{kg} / 100 \mathrm{~m}^{2}\right)$ & $7.64 \pm 0.90^{\mathrm{b}}$ & $9.05 \pm 0.03^{\mathrm{ab}}$ & $11.05 \pm 0.28^{\mathrm{a}}$ & $11.18 \pm .826^{\mathrm{a}}$ \\
\hline \multicolumn{5}{|l|}{ Bighead carp } \\
\hline Initial mean weight (g/fish) & $20.51 \pm 10.10^{\mathrm{a}}$ & $3.43 \pm 0.44^{\mathrm{b}}$ & $3.13 \pm 0.34^{\mathrm{b}}$ & $3.99 \pm 0.33^{\mathrm{b}}$ \\
\hline Initial total weight $\left(\mathrm{kg} / 100 \mathrm{~m}^{2}\right)$ & $0.52 \pm 0.25$ & $0.08 \pm 0.01$ & $0.07 \pm 0.01$ & $0.09 \pm 0.01$ \\
\hline Final mean weight (g/fish) & $283.86 \pm 15.02^{\mathrm{ab}}$ & $189.20 \pm 22.34^{\mathrm{b}}$ & $289.00 \pm 14.37^{\mathrm{ab}}$ & $326.60 \pm 67.62^{\mathrm{a}}$ \\
\hline Final total weight $\left(\mathrm{kg} / 100 \mathrm{~m}^{2}\right)$ & $3.13 \pm 0.11^{\mathrm{ab}}$ & $2.41 \pm 0.27^{\mathrm{b}}$ & $3.93 \pm 0.26^{\mathrm{a}}$ & $4.33 \pm 0.53^{\mathrm{a}}$ \\
\hline Survival (\%) & $73.5 \pm 3.7$ & $88.4 \pm 8.6$ & $84.9 \pm 8.6$ & $90.6 \pm 2.3$ \\
\hline Daily weight gain (g/f/d) & $0.81 \pm 0.07$ & $0.68 \pm 0.08$ & $1.06 \pm 0.05$ & $1.19 \pm 0.24$ \\
\hline Total weight gain $\left(\mathrm{kg} / 100 \mathrm{~m}^{2}\right)$ & $2.60 \pm 0.25^{\mathrm{b}}$ & $2.32 \pm 0.27^{\mathrm{b}}$ & $3.86 \pm 0.26^{\mathrm{a}}$ & $4.24 \pm 0.53^{\mathrm{a}}$ \\
\hline \multicolumn{5}{|l|}{ Rohu } \\
\hline Initial mean weight (g/fish) & $27.56 \pm 2.78$ & $36.48 \pm 2.42$ & $28.50 \pm 3.77$ & $41.26 \pm 5.50$ \\
\hline Initial total weight $\left(\mathrm{kg} / 100 \mathrm{~m}^{2}\right)$ & $0.42 \pm 0.03$ & $0.56 \pm 0.02$ & $0.42 \pm 0.05$ & $0.62 \pm 0.08$ \\
\hline Final mean weight (g/fish) & $427.73 \pm 45.73$ & $347.65 \pm 28.74$ & $361.42 \pm 48.79$ & $371.39 \pm 8.03$ \\
\hline Final total weight $\left(\mathrm{kg} / 100 \mathrm{~m}^{2}\right)$ & $8.27 \pm 0.14$ & $7.78 \pm 0.79$ & $7.11 \pm 0.78$ & $8.16 \pm 0.52$ \\
\hline Survival (\%) & $77.3 \pm 15.7$ & $92.4 \pm 0.1$ & $87.9 \pm 3.4$ & $78.7 \pm 8.9$ \\
\hline Daily weight gain (g/f/d) & $1.47 \pm 0.16$ & $1.15 \pm 0.09$ & $1.23 \pm 0.16$ & $1.22 \pm 0.02$ \\
\hline Total weight gain $\left(\mathrm{kg} / 100 \mathrm{~m}^{2}\right)$ & $7.84 \pm 0.14$ & $7.32 \pm 0.76$ & $6.69 \pm 0.75$ & $7.54 \pm 0.44$ \\
\hline \multicolumn{5}{|l|}{ Mrigal } \\
\hline Initial mean weight (g/fish) & $8.08 \pm 0.48$ & $7.51 \pm 3.81$ & $4.29 \pm 0.87$ & $6.57 \pm 2.30$ \\
\hline
\end{tabular}


Table 2-Contd....

M.C. Gupta and S. Rai / Our Nature (2011) 9: 112-118

\begin{tabular}{lcccc} 
Initial total weight $\left(\mathrm{kg} / 100 \mathrm{~m}^{2}\right)$ & $0.17 \pm 0.00$ & $0.15 \pm 0.07$ & $0.08 \pm 0.00$ & $0.13 \pm 0.05$ \\
Final mean weight $(\mathrm{g} / \mathrm{fish})$ & $278.92 \pm 45.73$ & $340.71 \pm 36.52$ & $352.13 \pm 74.96$ & $437.36 \pm 49.19$ \\
Final total weight $\left(\mathrm{kg} / 100 \mathrm{~m}^{2}\right)$ & $5.26 \pm 0.75$ & $6.47 \pm 0.52$ & $6.39 \pm 1.44$ & $7.78 \pm 1.30$ \\
Survival $(\%)$ & $94.3 \pm 2.7$ & $88.9 \pm 4.1$ & $95.0 \pm 3.3$ & $90.7 \pm 4.8$ \\
Daily weight gain $(\mathrm{g} / \mathrm{f} / \mathrm{d})$ & $1.00 \pm 0.11$ & $1.23 \pm 0.14$ & $1.29 \pm 0.27$ & $1.59 \pm 0.17$ \\
Total weight gain $\left(\mathrm{kg} / 100 \mathrm{~m}^{2}\right)$ & $5.09 \pm 0.75$ & $6.33 \pm 0.60$ & $6.30 \pm 1.54$ & $7.66 \pm 1.27$ \\
\hline
\end{tabular}

Mean values with different superscript letters in the same row are significantly different $(\mathrm{P}<0.05)$.

Table 3. Growth performance of Dedhuwa, Mara and Pothi in different treatments (Mean \pm S.E.).

\begin{tabular}{|c|c|c|c|c|}
\hline \multirow{2}{*}{ Parameters } & \multicolumn{4}{|c|}{ Treatments } \\
\hline & $T_{1}$ & $\mathbf{T}_{2}$ & $T_{3}$ & $\mathbf{T}_{4}$ \\
\hline \multicolumn{5}{|l|}{ Dedhuwa } \\
\hline Initial mean weight (g/fish) & - & $0.98 \pm 0.00$ & - & - \\
\hline Initial total weight $\left(\mathrm{kg} / 100 \mathrm{~m}^{2}\right)$ & - & $0.43 \pm 0.00$ & - & - \\
\hline Final total weight $\left(\mathrm{kg} / 100 \mathrm{~m}^{2}\right)$ & - & $2.98 \pm 1.78$ & - & - \\
\hline Total wt. gain $\left(\mathrm{kg} / 100 \mathrm{~m}^{2}\right)$ & - & $2.56 \pm 1.80$ & - & - \\
\hline \multicolumn{5}{|l|}{ Mara } \\
\hline Initial mean weight (g/fish) & - & - & $1.39 \pm 0.00$ & - \\
\hline Initial total weight $\left(\mathrm{kg} / 100 \mathrm{~m}^{2}\right)$ & - & - & $0.29 \pm 0.00$ & - \\
\hline Final total weight $\left(\mathrm{kg} / 100 \mathrm{~m}^{2}\right)$ & - & - & $1.27 \pm 0.13$ & - \\
\hline Total wt. gain $\left(\mathrm{kg} / 100 \mathrm{~m}^{2)}\right.$ & - & - & $0.98 \pm 011$ & - \\
\hline \multicolumn{5}{|l|}{ Pothi } \\
\hline Initial mean weight ( $\mathrm{g} /$ fish) & - & - & - & $1.94 \pm 0.36$ \\
\hline Initial total weight $\left(\mathrm{kg} / 100 \mathrm{~m}^{2}\right)$ & - & - & - & $0.58 \pm 0.01$ \\
\hline Final total weight $\left(\mathrm{kg} / 100 \mathrm{~m}^{2}\right)$ & - & - & - & $4.62 \pm 0.91$ \\
\hline Total wt. gain $\left(\mathrm{kg} / 100 \mathrm{~m}^{2}\right)$ & - & - & - & $4.04 \pm 0.92$ \\
\hline
\end{tabular}

Mean values with different superscript letters in the same row are significantly different $(\mathrm{P}<0.05)$.

$\underline{\text { Table 4. Extrapolated net yield of Carp, SIS and combined total net fish yield (t/ha/yr) and AFCR (Mean } \pm \text { S.E.) }}$

\begin{tabular}{lcccc}
\hline \multicolumn{1}{c}{ Parameters } & \multicolumn{4}{c}{ Treatments } \\
\cline { 2 - 5 } & $\mathbf{T}_{\mathbf{1}}$ & $\mathbf{T}_{\mathbf{2}}$ & $\mathbf{T}_{\mathbf{3}}$ & $\mathbf{T}_{\mathbf{4}}$ \\
\hline Carp (t/ha/yr) & $3.13 \pm 0.20^{\mathrm{b}}$ & $3.38 \pm 0.21^{\mathrm{ab}}$ & $3.77 \pm 0.29^{\mathrm{ab}}$ & $4.14 \pm 0.29^{\mathrm{a}}$ \\
Dedhuwa (t/ha/yr) & - & $0.39 \pm 0.27$ & - & - \\
Mara (t/ha/yr) & - & - & $0.15 \pm 0.11$ & - \\
Pothi (t/ha/yr) & - & - & - & $0.61 \pm 0.14$ \\
Total (t/ha/yr) & $3.13 \pm 0.20^{\mathrm{b}}$ & $3.77 \pm 0.51^{\mathrm{ab}}$ & $3.92 \pm 0.31^{\mathrm{ab}}$ & $4.75 \pm 0.38^{\mathrm{a}}$ \\
AFCR & $3.2 \pm 0.11$ & $2.6 \pm 0.38$ & $2.6 \pm 0.02$ & $2.5 \pm 0.04$ \\
\hline
\end{tabular}

Mean values with different superscript letters in the same row are significantly different $(\mathrm{P}<0.05)$.

Table 5. Economic analysis of different treatments based on $100 \mathrm{~m}^{2}$ pond in Nepalese currency (NRs) during experimental period

\begin{tabular}{lcccc}
\hline \multirow{2}{*}{ Variables } & \multicolumn{4}{c}{ Treatments } \\
\cline { 2 - 5 } & $\mathbf{T}_{\mathbf{1}}$ & $\mathbf{T}_{\mathbf{2}}$ & $\mathbf{T}_{\mathbf{3}}$ & $\mathbf{T}_{\mathbf{4}}$ \\
\hline Gross Return & $4,889 \pm 336^{\mathrm{b}}$ & $5,186 \pm 308^{\mathrm{ab}}$ & $5,720 \pm 444^{\mathrm{ab}}$ & $6,314 \pm 454^{\mathrm{a}}$ \\
Carp & - & $387 \pm 232$ & - & - \\
Dedhuwa & - & - & $165.79 \pm 31.37$ & - \\
Mara & - & - & - & $601 \pm 118$ \\
Pothi & $4,889 \pm 336^{\mathrm{b}}$ & $5,573 \pm 679^{\mathrm{ab}}$ & $5,885 \pm 463^{\mathrm{ab}}$ & $6,915 \pm 501^{\mathrm{a}}$ \\
Total Gross Return & & 116 &
\end{tabular}


M.C. Gupta and S. Rai / Our Nature (2011) 9: 112-118

\begin{tabular}{|c|c|c|c|c|}
\hline \multicolumn{5}{|l|}{$\begin{array}{l}\text { Table 5-Contd.... } \\
\text { Variable Cost }\end{array}$} \\
\hline Lime & 50 & 50 & 50 & 50 \\
\hline Feed & $1,402 \pm 145$ & $1,269 \pm 309$ & $1,472 \pm 269$ & $1,657 \pm 252$ \\
\hline Urea & 531 & 531 & 531 & 531 \\
\hline DAP & 180 & 180 & 180 & 180 \\
\hline Carp fingerlings & 100 & 100 & 100 & 100 \\
\hline SIS & - & 150 & 150 & 150 \\
\hline Total Variable Cost & $2,263 \pm 145$ & $2,280 \pm 309$ & $2,483 \pm 269$ & $2,668 \pm 252$ \\
\hline Gross Margin $\left(100 \mathrm{~m}^{2}\right)$ & $2,626 \pm 199^{\mathrm{b}}$ & $3,293 \pm 387^{b}$ & $3,402 \pm 196^{\mathrm{b}}$ & $4,247 \pm 283^{\mathrm{a}}$ \\
\hline $\begin{array}{l}\text { Gross Margin (in'000) } \\
(\text { NRs/h/yr) }\end{array}$ & $354.24 \pm 52.12^{b}$ & $445.25 \pm 214.90^{b}$ & $459.90 \pm 113.09^{b}$ & $574.13 \pm 106.53^{\mathrm{a}}$ \\
\hline
\end{tabular}

(1992), Shahabuddin et al. (1994), Mazid et al. (1997), Abbas et al. (2010), Rehman et al. (2006) and Yadav (2011) from Carp polyculture system. The net Carp yield in the present experiment was lower than those reported by Wahab et al. (1995) of 2,225 $\mathrm{kg} / \mathrm{ha}$ in 120 days (equivalent to $6,767 \mathrm{~kg} / \mathrm{ha} / \mathrm{yr}$ ), Jena et al. (2002) of $5,843.75 \mathrm{~kg} / \mathrm{ha}$ and Lakshmanan et al. (1971) of 2,229 to $4,209 \mathrm{~kg} / \mathrm{ha} / \mathrm{yr}$.

The overall result showed that SIS did not have adverse effect on growth and production of Carp. Production of Carp was better in SIS added ponds. Adding SIS in appropriate density enhanced Carp production. Production of Carp was higher in SIS treatments. This can be attributed to partial harvesting system of SIS which regular thinned the population of SIS and maintained appropriate density in ponds. Moreover, SIS might be compatible to Carp as reported by Wahab et al. (2003), Alim et al. (2005), Kadir et al. (2006) and Yadav (2011). Though all treatments were profitable but gross margin was highest in Pothi added treatment due to higher total production. Based on production and profit, Carp-Pothi polyculture treatment appears to be best among the treatments. Since adding SIS to Carp polyculture ponds increased the Carp production and profit, there is a need of such studies with other nutrient rich SIS so that more rural poor will be benefited.

\section{Acknowledgements}

The authors wish to thank Department of Aquaculture, IAAS and fish farmers of Khaireni, Majhui, Chitwan, Kamla Gharti and Ramesah Jaiswal for their help to carry out the research. This research is a component of DANAIDA-SIS project.

\section{References}

Abbas, S., I. Ahmed, M. Salim and K. Rehman 2010. Comparative effects of fertilization and supplementary feed on growth performance of three fish species. International Journal Agriculture Biololgy 12: 276-280.

Alim, M.A., M.A. Wahab and A. Milstein 2005 Effects of increasing the stocking density of large carp by $20 \%$ on 'cash' carp-small fish polyculture of Bangladesh. Aquaculture Res. 36(4): 317-325.

Boyd, C.E. 1990. Water quality in ponds for aquaculture. Alabama. 482p.

Jena, J.K., S. Ayyappan and P.K. Aravindakshan 2002. Comparative evaluation of production performance in varied cropping patterns of carp polyculture systems. Aquaculture 207: 49-64.

Kadir, A., R.S. Kundu, A. Milstein and M.A. Wahab 2006. Effects of Silver carp and small indigenous species on pond ecology and carp polycultures in Bangladesh. Aquaculture 261(3): 1065-1076.

Lakshamanan, M.A.V., K.K. SukuMaranan, D.S. Murty, D.P. Chakraborty and M.T. Philipose 


\section{M.C. Gupta and S. Rai / Our Nature (2011) 9: 112-118}

1971. Preliminary observation on intensive fish farming in fresh water ponds by the composite culture of Indian and exotic species. Journal of Inland Fish Society 2: 1-21.

Mazid, M.A., M. Zaher, N.N. Begum, M.Z. Ali and F. Nahar 1997. Formulation of cost effective feeds from locally available ingredients for carp polyculture systems for increased production. Aquaculture 151: 71-78.

Miah, M.J.U. and W.H. Siddiqude 1992. Studies on the food and feeding habits of Mola, Amblypharyngodon mola. Bangladesh Journal of Agricultural Science 19(2): 165-170.

Rehman, M.M., M.C.J. Verdegema, L.A.J. Nagelkerke, M.A. Wahab, A. Milstein and J.A.J. Verreth 2006. Growth, production and food preference of rohu Labeo rohita (H.) in monoculture and in polyculture with common carp Cyprinus carpio (L.) under fed and non-fed ponds. Elsevier Aquaculture 257: 359-372.

Roos, N., M.A. Wahab, C. Chamman and S.H. Thilsted 2006. Understanding the links between Agriculture and Health. 2020 vision for Food, Agriculture, and Environment. International Food Policy Research. 2033 K Street, N.W. Washington, D.C. 20006-1002. U.S.A. Focus, brief 10 of 16 .

Roos, N., M.A. Wahab, C. Chamman and S.H. Thilsted 2007. The role of fish in food based strategies to combat vitamin $A$ and mineral deficiencies in developing countries. Presented in symposium: Food-based approaches to combating micronutrient deficiencies in children of developing countries. 12-15 December, Bangladesh. 65p.

Shahabuddin, M., M.S. Miah and M.S. Alam 1994 Study on production optimization through polyculture of indigenous and exotic carp Bangladesh Journal of Training and Development 7(2): $67-72$.

Shrestha, M.K. and N.P. Pandit 2007. A textbook of principle of aquaculture. Department of Aquaculture, Institute of Agriculture and Animal Science, Rampur, Chitwan, Nepal. pp. 38-44.

Wahab, M.A. and A. Kadir 2009. Polyculture of Punti and Mola with carp. Bangladesh Agriculture University, Mymensingh, Dhaka, Bangladesh. 6p.

Wahab, M.A., M.A. Alim and A. Milstein 2003. Effects of adding the small fish Punti (Puntius sophore) and/or Mola (Amblypharyngodon mola) to a polyculture of large carp. Aquaculture Research 34(2): 149-164.

Wahab, M.A., Z.F. Ahmed, M.A. Islam, M.S. Haq and M. Rohamatullah 1995. Effects of introduction Common carp (Cyprinus carpio L) on the pond ecology and growth of fish in polyculture. Aquaculture Research 26: 219-228.

Yadav, S.K. 2011. Production potential of Carp-small indigenous fish species- Prawn polyculture in Chitwan, Nepal. Institute of Agriculture and Animal Science (IAAS), Rampur, Chitwan, Nepal. (M.Sc. Thesis). 